\title{
An Analysis of English Education Model in Vocational Colleges in the Internet Era
}

\author{
Weng Jie \\ Xi'an Peihua University, Xi'an 710125 China
}

\begin{abstract}
Keywords: Internet plus; Network technology; Economic form; Higher vocational English; Reform and innovation

Abstract. Nowadays, people live in the Internet age. In the era of network technology highly developing, people have proposed the new term "Internet plus". It is a new economic form that USES the Internet to enhance economic value. In the Internet era, English teaching in higher vocational colleges has carried out positive reform in student management and education by using Internet technology, forming a unique English teaching model in the Internet era. This greatly improves the quality of education in higher vocational colleges. By analyzing the influence of "Internet plus" on English teaching in higher vocational colleges, this paper puts forward the reform and innovation method of English teaching mode in higher vocational colleges in the era of "Internet plus".
\end{abstract}

\section{Introduction}

In the Internet age, people have already deeply understood the concept of "Internet plus". In this age of Internet development, information technology changes with each passing day. Economic globalization has already stepped onto the world stage due to the existence of the Internet. Therefore, the Internet is cited by all walks of life, including the English education of vocational colleges. The talent market attaches great importance to talents with English skills. Higher vocational colleges should adapt to the changes of The Times, make use of the characteristics of the Internet era to carry out the reform of teaching mode, and cultivate excellent English talents for the society.

\section{The Influence of "Internet Plus" on the English Teaching Mode of Higher Vocational Colleges}

\subsection{The roles of teachers and students have changed}

The traditional teaching mode of the English teaching model of most vocational colleges is still used. English teaching depends on the teacher's knowledge of existing knowledge, which sees students as an indoctrinate container. This is not conducive to the development of students' personalities. Although the quality education is proposed in our country, it is necessary to treat students as the subject of learning, and the teacher's role is only a guide and author of the author. However, most vocational colleges in China have not implemented this policy. The advent of the Internet solves the problem perfectly. The Internet age is an age of information resource sharing. Students have more opportunities to meet new knowledge. This enriches the knowledge of students learning English. Network resources can allow teachers to improve their teaching level. It allows teachers to think actively and actively thinking about how to conduct teaching can receive good results, think from the perspective of learning, and actively guide students to study independently. Teachers will pay more attention to the students' learning ability, so that the real realization of the identity transformation of teachers and students. The teacher is no longer the master of the teaching, but a guide to knowledge. Students are also truly the masters of learning.

\subsection{Arouse students' interest in learning}

There is a growing demand for English professionals in the market. The enrollment of English majors in vocational colleges has been increasing in recent years. The heavy teaching tasks make teachers ignore the innovation of teaching model [1]. Traditional teaching methods, such as teaching students to read and remember words, are very boring. The teacher explained the English text in a single way. Students can only take notes with numbness. This will cause students to gradually lose interest in English learning, and even develop a sense of disgust. Although some vocational colleges have extracurricular activities to 
communicate in English, there are few participants. In the Internet age, the traditional English teaching model weakness was found by people gradually, the arrival of the Internet for students is a new things, put it into English teaching will greatly lift students' interest in English, remember the words, for example, students can learn by some interesting software, can achieve the purpose of learning, and can let students feel happy during the learning process; Students can learn some foreign customs through the Internet, so that they can get access to the language of foreigners and integrate their language into the English knowledge they have learned. Students can deeply experience the English learning environment. Students can also open online courses, and foreign students learn together, make progress together, students can according to your own time effectively arrange his own study, comparing with the learning gap between foreign students and can arouse the students' learning motivation in English, communicate with foreign students, to stimulate students' interest in learning English.

\subsection{Improve the comprehensive quality of students}

In the traditional English teaching model, teachers are completely dependent on textbooks. The teacher teaches through a detailed curriculum. Their teaching only focuses on the content of teaching and ignores the universality and practicality of knowledge. In order to cultivate talents needed by the society, higher vocational college must pay attention to the cultivation of students' practical ability to use English. However, at present, the English teaching in higher vocational college is still affected by exam-oriented education and only pays attention to students' scores. The teacher's word grammar in class is too boring. Teachers do not teach students how to apply what they learn to their daily lives. Such English teaching model cannot cultivate professional talents suitable for the society [2]. In the Internet era, the continuous progress of science and technology has made great changes to students' learning methods. The emergence of the Internet has made it more convenient for students to learn English. It realizes the organic integration of online and offline, and students can share resources through the network, which not only satisfies the principle of students as the subject of learning, but also enables students to keep up with the pace of The Times, and imperceptibly improves the comprehensive quality of students.

\section{Current Status of English Teaching Mode in Higher Vocational Colleges}

\subsection{Unclear teaching objectives}

Higher vocational education is different from higher education. The teaching goal of education in higher vocational colleges is to cultivate applied senior talents with certain practical ability. The subject set up by higher vocational colleges should be highly specific and practical. In English teaching in higher vocational colleges, teachers should comprehensively improve students' English ability, so that students can adapt to their professional work in the society [3]. However, most of higher vocational colleges in China have adopted the traditional teaching mode and paid little attention to the cultivation of students' practical application of English, resulting in a serious disconnection between students and the society.

\subsection{The textbook is out of date}

Due to the increasing demand for English talents in the society, higher vocational colleges have more and more students every year. But there are not enough teachers in higher vocational colleges. As a result, teachers in higher vocational colleges undertake heavy teaching tasks and have no time or experience to write special textbooks for higher vocational colleges. At present, the teaching materials used by higher vocational colleges in China are the integration and modification of the teaching materials of undergraduate and junior colleges. Many contents of the textbook do not conform to the features of education in higher vocational colleges. Even with the progress of The Times, some universities still use old textbooks. This leads to outdated teaching content, which makes students keep up with the pace of The Times [4].

\subsection{Weak faculty}

At present, most of higher vocational colleges in China are transformed from technical secondary schools. The equipment of English teaching is backward. This is not conducive to the teaching quality of English, or to the realization of the teaching objectives of higher vocational colleges [5]. In recent years, 
higher vocational colleges have been increasing the number of students, but they do not pay attention to the construction of teachers. As a result, teachers have heavy teaching tasks, no time and energy to carry out teaching research and the overall teaching level cannot be improved, seriously hindering the development of students.

\subsection{Cannot teach according to aptitude}

China's vast territory, the current situation of education is different from each other. Students in vocational colleges come from all over the world and have different English backgrounds. For students with different foundation, the teaching mode of higher vocational colleges may be too simple for students with good foundation and waste students' time. But it is more difficult for students with poor foundation. In recent years, the number of students in higher vocational colleges keeps increasing, and the student structure in higher vocational colleges will become more and more complex. Therefore, the teaching model of higher vocational colleges must be reformed as soon as possible.

\section{Reform of Education Model in Higher Vocational Colleges under the Environment of Internet Plus}

\subsection{Build platforms with internet technology}

The transformation of teaching mode in higher vocational colleges depends on the background of "Internet plus". In order to adapt to the changes of The Times, China proposed to carry out education reform vigorously. People can use information technology, intelligent services and other means to help students learn English better. Internet technology enhances students' practical application ability and improves their comprehensive quality. Specific practices such as: higher vocational colleges and universities to create a public platform, micro letter on this platform can to release the relevant knowledge of English and summary, also can release some folk customs, some foreign construction in higher vocational colleges and universities study atmosphere, make students feel the atmosphere of learning, anytime and anywhere to make learning become a habit of students. In this way, the teaching mode built on the Internet can enrich the teaching content of higher vocational colleges and greatly improve students' interest in learning, thus continuously improving the teaching level of higher vocational colleges.

\subsection{Adopt dynamic teaching mode}

Under the background of "Internet plus" era, colleges and universities in higher vocational colleges can use different learning model, learning effect, learning means to have a thorough understanding of English subject knowledge and the connection between the inner and outer, colleges and universities can use the Internet for data analysis in higher vocational colleges, put forward a better method of study, actively create a learning situation for students, let students keep learning rule, colleges and universities actively collect students' feedback in higher vocational colleges, higher vocational colleges so as to promote college students in the learning process progress. Vocational colleges use the Internet to realize the dynamic teaching content, and use various learning models to analyze the reasons why students' English learning is affected. Such in-depth analysis can enable teachers to fully understand students' learning effect and make positive and effective measures through scientific prediction effect. For the reform of the teaching mode of higher vocational colleges, the teaching contents should be presented flexibly, so that students can constantly understand the multi-angle of learning English, realize the cultivation of divergent thinking of students, and constantly improve the application ability of students in higher vocational colleges to English [6]. Such as colleges and universities can take advantage of "Internet plus" has real-time monitoring of students learning English, the formation of college students learning data analysis data in higher vocational colleges, to find suitable teaching methods, from the data analysis to dynamic analysis of data, to guide higher vocational colleges and universities development towards a better, higher vocational colleges universities, dynamic management of teaching with "Internet plus", and make the higher vocational colleges and universities to realize dynamic development, in a constantly changing dynamic data, to find effective resources, conducive to the development of higher vocational colleges universities form a dynamic resource database is beneficial to the development of higher vocational 
colleges universities, It lays a solid foundation for the long-term stable development of higher vocational colleges.

\subsection{Constructing learning situations}

With the continuous development of Internet technology, teachers in higher vocational colleges start to use the Internet to create learning situations for students and realize the experiential teaching mode for students. Such experiential teaching enables students to learn by themselves and make continuous progress in the experience. Such as colleges and universities of today's vocational colleges will give students playing movies in English lesson, in this process, teachers use multimedia teaching software, lets the student access to authentic English accent, and strengthen the application of vocabulary and sentence impression, lets the student in subtle when you watch the movie plot to consolidate and improve the students' English knowledge, improve the efficiency of student learning, to enhance the students' autonomous learning ability. At the same time, higher vocational colleges can use "Internet plus" to develop special software suitable for English teaching, so that students can realize the learning state of "playing while learning". Teachers can also use Internet technology to build a QQ group in the class, publish some English learning documents and video in the group, and assign homework in the group, use video for English dialogue and so on. All of these teaching methods are attached to "Internet plus", and at the same time, higher requirements are put forward for the operation and application of teachers. "Internet plus" can bring more teaching tools to English teaching in higher vocational colleges, and making good use of these tools will greatly improve students' English level.

\section{Conclusion}

English teaching is an important part of higher vocational colleges. At present, the quality of English teaching in higher vocational colleges in China is relatively low. This is not only because teachers have problems in teaching, but also students have their own problems. There are some problems in higher vocational colleges, such as imperfect teaching equipment and low usage rate of equipment. Therefore, to improve the level of English teaching in vocational colleges, we must adapt to the characteristics of the development of The Times and make use of "Internet plus" to reform the English teaching mode. Higher vocational colleges should change the traditional teaching mode and integrate the Internet into the current teaching mode. They should make use of Internet technology to enrich the teaching content and improve the quality of English teaching. English education in higher vocational colleges should conform to its educational purpose and cultivate professional English talents with practical ability. But in the Internet age, the shortcomings of the traditional teaching model are gradually revealed. Therefore, higher vocational colleges must change their traditional teaching mode and use "Internet plus" to realize the transformation of English teaching mode in higher vocational colleges. They should make use of the high-end technology of the Internet to create the special English teaching mode of higher vocational colleges under the background of "Internet plus", so as to improve the English teaching level of higher vocational colleges and constantly train advanced practical talents for the society.

\section{References}

[1] $\mathrm{Xu}$ Yao. Construction of English teaching model in vocational colleges under the network environment [J]. English Square (academic research).2014 (01):102-103

[2] Lv Shifang. A brief analysis of the construction of English teaching mode in higher vocational colleges under the network environment [J]. Intelligence.2014 (16):248-249

[3] Yang Jun. On the change of teacher's role in the course of "individualized teaching" in colleges and universities [J]. Exploration of Education.2007 (9):84-85

[4] Tian Guangzeng, Wu Xiaolu. Research on the difference between teachers and students' evaluation of teachers' ethics in universities [J]. Education Theory and Practice.2016 (15):48-50 
[5] Xiong Mei. Bu Qinggang. Practical exploration of personalized teaching organization form [J]. Chinese Journal of Education.2014 (7):42-47

[6] Spruce. Cultural self-consciousness, cultural self-confidence, cultural self-improvement-thoughts on the prosperity and development of socialist culture with Chinese characteristics (middle) [J]. Red Flag Manuscript 2010 (16) 